ENTREPRENEURSHIP AND SUSTAINABILITY ISSUES

ISSN 2345-0282 (online) http://jssidoi.org/jesi/

2020 Volume 8 Number 2 (December)

http://doi.org/10.9770/jesi.2020.8.2(22)
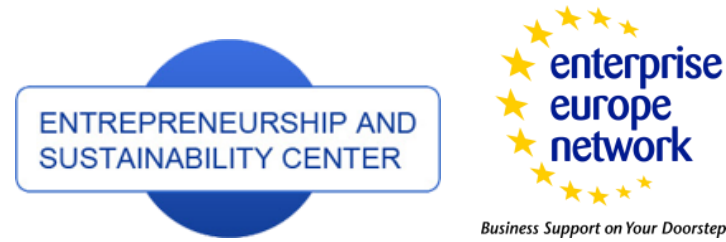

Business Support on Your Doorstep
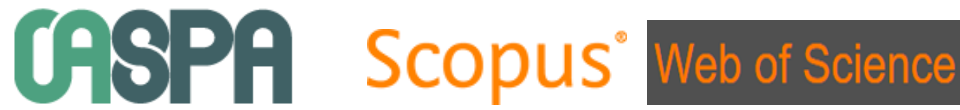

http://jssidoi.org/esc/home

\title{
Clarivate
Analytics \\ STRATEGIC MANAGEMENT OF HUMAN RESOURCES IN MODERN CONDITIONS: A CASE STUDY
}

\author{
Olga V. Tolstyakova ${ }^{1}$, Nazygul T. Batyrova ${ }^{2}$ \\ ${ }^{1}$ Higher School of Tariff Regulation, Plekhanov Russian University of Economics, 117997, 36 Stremiannyy Lane, Moscow, \\ Russian Federation \\ ${ }^{2}$ Higher School of Public Administration and Economics, Akhmet Yassawi International Kazakh-Turkish University, 161205, \\ 29 B. Sattarkhanov Ave, Turkestan, Republic of Kazakhstan \\ E-mails: ${ }^{1}$ o.tolstyakova5646-2@uohk.com.cn; ${ }^{2}$ naz.batyrova5187@tanu.pro
}

Received 16 December 2019; accepted 21 August 2020; published 30 December 2020

\begin{abstract}
The relevance of the subject matter is conditioned by the fact that human resources are an invaluable asset of any organisation, institution, or industrial enterprise. The purpose of the paper is to develop recommendations for managing human resources. The leading methods of researching the problems of the paper include the analysis of theoretical sources, the analysis of statistical indicators, and comparison. Analysis of statistical indicators plays a crucial role in the study, since data on human resource management can be directly obtained from statistical databases. The paper investigates the concept of human resources, the essence of human resource management, the functions of the HR service, analyses the management of human resources at Russian enterprises (in the Khanty-Mansi Autonomous Okrug and the Yamalo-Nenets Autonomous Okrug), identifies management problems, and develops solutions to them. An effective system of performance appraisal, remuneration, and wage structure will increase the effectiveness of the approach to managing human resources, and will lead to fundamental changes in the worldview of the company's management in relation to its human resources. The materials of the paper are of practical value for improving the management of human resources at Russian enterprises.
\end{abstract}

Keywords: training; potential; enterprise; globalisation; modern economy

Reference to this paper should be made as follows: Tolstyakova, O.V., Batyrova, N.T. 2020. Strategic management of human resources in modern conditions. Entrepreneurship and Sustainability Issues, Entrepreneurship and Sustainability Issues, 8(2), $370-381$. http://doi.org/10.9770/jesi.2020.8.2(22)

JEL Classifications: G2, G3, H4, H7 


\section{ENTREPRENEURSHIP AND SUSTAINABILITY ISSUES}

ISSN 2345-0282 (online) http://jssidoi.org/jesi/

2020 Volume 8 Number 2 (December)

http://doi.org/10.9770/jesi.2020.8.2(22)

\section{Introduction}

Human resources play a decisive role in the development of a modern economy. Human resource management (HR management) is a collective term for all formal systems created to help manage employees and other stakeholders within an enterprise. Starting with finding the right workforce and ending with retaining the best workforce, the HR service strives to make smart recruitment decisions through human capital analysis (Meena, \& Parimalarani, 2019). The role of human resources management is to find the best way to increase enterprise productivity at the expense of its employees. The rational use of human resources of the enterprise allows more efficient use of equipment, machines, mechanisms, and as a result, production volumes, profit, and other economic indicators increase (Melnyk et al., 2019; Fedotov et al., 2018).

Despite the ever-increasing pace of change in the corporate world, the role of human resource management is unlikely to undergo dramatic changes. In recent years, several business tendencies have had a significant impact on human resources management. 21st century human resources management is becoming more efficient with the best use of technological advances (Reddy, \& Lakshmikeerthi, 2017; Yessilov, \& Kalashnikova, 2015). The main one is new technologies, especially in electronic communications, dissemination and information retrieval, which have radically changed the business landscape. Satellite communications, computers and network systems, fax machines and other devices - all this contributed to a change in the way enterprises interact with each other and their employees (Kerimov et al., 2018a; Kerimov et al., 2018b). For example, teleworking has become a very popular option for many employees, and human resource managers have had to develop new guidelines for this emerging subgroup of employees. Changes in the organisational structure have also affected the change in the nature of human resource management. In recent years, the number of trade unions in many industries has been declining, and organisational philosophy is changing. Many companies have abandoned or adjusted their conventional hierarchical organisational structures in favour of more flat management structures (Silagadze et al., 2019; Miethlich \& Šlahor, 2018).

The third factor of change was the acceleration of the globalisation of the market. This phenomenon has led to increased competition for both customers and jobs. Enterprises began to demand higher results from their employees. Other factors that have changed the nature of human resource management in recent years include new managerial and operational theories, rapidly changing demographics, and changes in government employment laws (Yessilov, 2015; Lapidus et al., 2018a; Lapidus et al., 2018b). The role of the human resources management service is constantly increasing. Currently, businesses need people with a new mindset to cope with a changing global environment. There is a need for reengineering HR processes. Career planning needs to be clearly defined for employees. Management should also encourage employee participation in decision making. The theoretical significance of the paper lies in the study of the essential and substantial features of human resource management in the enterprise. The practical significance of the paper lies in proposing areas for improving the management of human resources in the enterprise. The theoretical framework of the paper comprises fundamental developments on the subject matter, which were presented in the works of domestic and foreign authors (Tretyakova et al., 2020).

Many authors paid addressed the issues of human resource management in the enterprise and suggested ways to solve them. S. Zeidan and N. Itani (2020) consider that human resources analysis is important for working with human resources, upon implementing which enterprises face a lack of skills in analysing personnel data, poor IT infrastructure and insufficient business investments. The interconnection and interaction of effective human resources management and strategic planning allow organisations to achieve maximum success (Stewart, \& Brown, 2019). From the standpoint of D. Angrave and I. Kirkpatrick (2016), human resources management should consider both staff potential and shortcomings, HR service personnel should be involved in building an operational and strategic plan to develop better methods and approaches - in this case, the practice of working 


\section{ENTREPRENEURSHIP AND SUSTAINABILITY ISSUES}

ISSN 2345-0282 (online) http://jssidoi.org/jesi/

2020 Volume 8 Number 2 (December)

http://doi.org/10.9770/jesi.2020.8.2(22)

with personnel will lead to transformational changes. However, the literature does not contain any relevant studies of the problems of human resource management in specific enterprises, which will be further discussed herein.

\section{Literature Review}

Resources form a part and a fundamental framework of the enterprise, since the enterprise cannot function without resource supply. The most important results of effective resource potential management are minimising the costs of their storage and management, timely provision of the necessary amount of resources for uninterrupted production and maximising the level of satisfaction of the needs of consumers of enterprise products.

The enterprise possesses various resources:

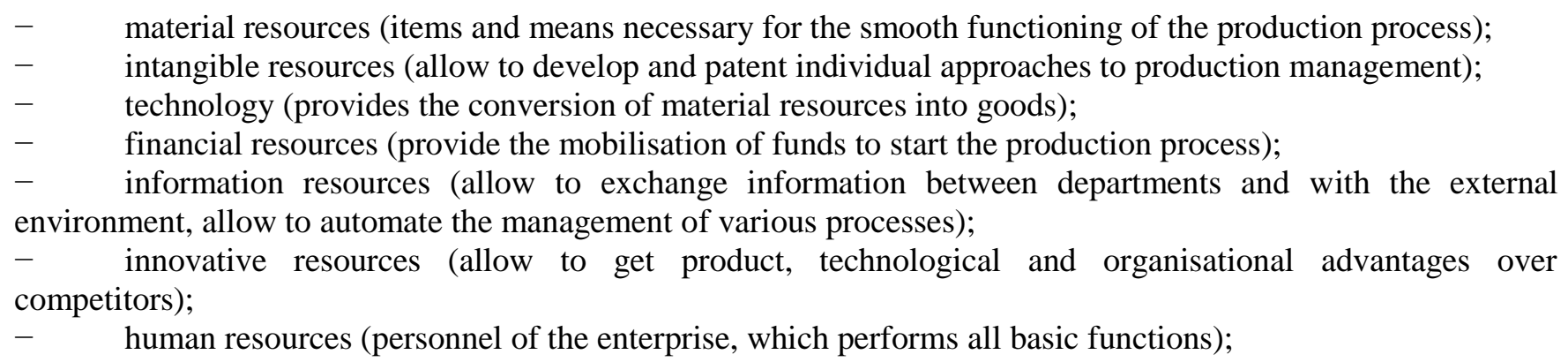

Human resources, therefore, constitute an important component of enterprise resources, including staff and workforce capacity. According to Z.Yu. Pronina (2018), human resource management is the employment, development, promotion of people in organisations and the development of appropriate relations between management and employees. HR management is the activity on the optimal use of personnel to achieve the goals of the enterprise, on the formation of personnel policy, corporate culture, management of human resources behaviour, management of social and labour relations (Lapshova, 2020).

HR management is based on the following basic principles. Firstly, human resources are the most important assets of an enterprise, and their effective management is the key to success. Secondly, personnel policy and personnel processes should be associated with the achievement of corporate goals and strategic plans. Thirdly, the corporate culture and values, the organisational climate and managerial behaviour arising from the corporate culture influence the results of the entire enterprise. Fourthly, HR management is involved in integration - involving all members of the enterprise in organisational practice and working together with the understanding of common tasks to achieve the goals of the enterprise (Konyavsky \& Ross, 2020; Bashynska, 2015).

The HR service develops programmes and activities aimed at helping meet both individual and organisational needs, goals, and objectives. With the help of human resources, it forms the appropriate corporate culture and implements programs that support the core values of the enterprise. Personnel workers study and analyse the environment, plan human resource requirements, recruit personnel in accordance with the needs of the enterprise, evaluate the labour behaviour of workers, establish compensation, improve working conditions, maintain effective labour relations (Dudin et al., 2016). Personnel workers aim at a qualitative improvement of the human resources of the enterprise, which are considered to be the most valuable assets (Miethlich \& Oldenburg, 2019).

The responsibilities of HR management can be divided into three categories: individual, organisational, and career responsibilities. Individual management involves assisting staff in identifying their strengths and weaknesses, correcting deficiencies and making the best contribution to the development of the enterprise. These 


\section{ENTREPRENEURSHIP AND SUSTAINABILITY ISSUES}

ISSN 2345-0282 (online) http://jssidoi.org/jesi/

2020 Volume 8 Number 2 (December)

http://doi.org/10.9770/jesi.2020.8.2(22)

responsibilities are carried out through various activities, such as validation, training and testing. Organisational development focuses on creating a successful system that maximises human (and other) resources as part of larger business strategies. This important responsibility also includes creating and managing a change program that allows the organisation to respond to changing external and internal influences. Finally, there is responsibility for managing career development. This entails the selection of people most suitable for certain jobs and the development of a career path within the enterprise (Frolova et al., 2020; Zatsepin et al., 2018).

The structures of HR services vary widely depending on the business, and are formed depending on the type, size, and guidelines of the enterprise. In recent years, staffing has changed due to internal organisational changes, as well as against the background of external changes (demography, globalisation, information technology) (BenGal, 2019). Currently the HR service is considered not as an administrative unit of the enterprise, but as a strategic business partner. The determining factor in supporting the long-term functioning of the enterprise and its development in a changing economic environment is the use of a strategic approach. Building an effective personnel strategy in close integration with the overall corporate strategy of the enterprise constitutes the framework for creating a competitive advantage based on the main element of any enterprise - its human resources. Accordingly, the leadership of modern organisations is facing a vexed question of choosing an effective personnel strategy that would meet the challenges of a changing external environment, but at the same time maintain and strengthen the competitive advantages inherent in organisations (Mukhamadiyeva et al., 2018).

Each company has its own preferences in the use of personnel management tools. Authors such as G.J. Bamber et al. (2017) believe that the creativity and innovation of human resources help challenge old ways of thinking and find new solutions to current problems. According to D. Ulrich (2016), lately, special attention has been paid to such features of human resources as determination, engagement, and welfare. An effective motivation system is important to attract and retain staff. An interested employee is a productive employee, which means a more profitable employee. The physical presence of a person does not guarantee their effective work. Only being at the workplace at their own free will and desire, the employee will make maximum effort, and not seek interest in other activities. It is motivation that drives human reserves. Labour motivation forms an integral part of the human resources management system, which constitutes a set of incentives that determine the main parameters of labour activity (Gorelov et al., 2016; Akizhanova et al., 2018).

Motivation can be material and non-material. Recently, the methods of motivation that produce results are as follows: bonus depending on the results of the work, holding contests, rewarding staff, financial support, conducting surveys, providing more freedom and flexibility in work, creating comfortable working and relaxing conditions, healthcare. For example, the founder of Radioactive Public Relations decided to try a four-day work week without reducing staff salaries. Six months later, the results spoke for themselves - the agency continued to conquer a new business, staff retention remained at 100\%, and the number of sick days was reduced by $75 \%$. Business revenue has more than doubled every year (Goodall, 2019). Mountain View organisation (California) pays special attention to the workplace environment - the campus area resembles old subway cars, there are conference rooms decorated in Broadway style. Google allows its software developers to design their own desktops or desktops made of what looks like huge Tinker toys. While some engineers have fixed tables, some others have additional treadmills that allow them to walk while working (Luenendonk, 2014).

\section{Materials and Methods}

The main method used in the analysis of human resource management is the analysis of statistical indicators. Large companies publish information on personnel and social policies and personnel statistics on their websites; the author selects the following indicators: staffing levels; staff turnover; number of employees taking part in training events; skill level of employees; staffing level. With that, to calculate individual indicators, it is necessary to study data for several years (those indicators were considered, that were available in the annual reports of 


\section{ENTREPRENEURSHIP AND SUSTAINABILITY ISSUES}

ISSN 2345-0282 (online) http://jssidoi.org/jesi/

2020 Volume 8 Number 2 (December)

http://doi.org/10.9770/jesi.2020.8.2(22)

individual companies under study). As the empirical framework of the study, we selected indicators for human resource management of companies located in the Yamalo-Nenets Autonomous Okrug and the Khanty-Mansi Autonomous Okrug.

It is important to describe the enterprises of the Yamalo-Nenets Autonomous Okrug and the Khanty-Mansi Autonomous Okrug. Khanty-Mansi Autonomous Okrug is a large oil and gas region of the Russian Federation and one of the largest oil-producing regions in the world. Yamalo-Nenets Autonomous District ranks 1st in Russia in terms of production of natural gas and gas condensate, oil is also produced here. The vast majority of successful companies in the Khanty-Mansi Autonomous Okrug and the Yamalo-Nenets Autonomous Okrug represent the oil and gas industry, gas and oil transport, and equipment for this industry.

The study of the problem was carried out in three stages:

- $\quad$ at the first stage, a theoretical analysis of the existing methodological approaches to the analysis of human resource management was carried out, statistical indicators were selected for analysis;

- $\quad$ at the second stage, the selected indicators were studied in dynamics, indicators for different enterprises were compared;

- $\quad$ at the third stage, general conclusions were drawn regarding human resource management at enterprises of the Tyumen region, proposals were developed to change the situation for the better.

\section{Results}

We shall consider the features of human resource management on the example of individual enterprises of the Tyumen region: UTEC-Koda JSC, Rosseti PJSC, Tyumen Rosseti JSC (formerly Tyumenenergo JSC until 2019), Surgutneftegaz PJSC. In UTEK-Koda JSC (Khanty-Mansi Autonomous Okrug) personnel work includes the processes of selection, fitting, hiring, placement, motivation, and staff training. The average headcount is 130 people (according to data for 2019). If we consider the management of personnel motivation at UTEC-Koda JSC, then the following methods of stimulating employees were developed there:

- $\quad$ employees receive cash compensation in honour of a professional holiday (Power Engineers' Day) in an amount that depends on the financial situation at the enterprise;

- $\quad$ at the birth of a child, financial aid is provided in the amount of 10 thousand roubles;

- $\quad$ on birthday -50 years, and then every 5 years a paid day off is provided and 10 thousand roubles are given out as material aid;

- $\quad$ upon reaching 30, 35, 40, 45 years, 5 thousand roubles are given;

- $\quad$ one of the family members of the deceased employee of the enterprise (due to disease, accident not at work) is aided 15 thousand roubles;

- $\quad$ reimbursement of the burial expenses in case of death of an employee as a result of a production-related accident, as well as the death of a disabled person resulting from a work injury at the enterprise or occupational disease, at the lowest rates, but not exceeding 25 thousand roubles;

- $\quad$ in case of death of close relatives, financial aid is allocated to employees of the enterprise in the amount of 10 thousand roubles;

- $\quad$ in cases of natural disasters, emergencies, fires, floods, etc., financial aid is allocated to employees -25 thousand roubles;

- $\quad$ the costs of preschool education are compensated to parents (employees of the enterprise);

- transport expenses (excluding taxis) are paid to employees for travel to the place of vacation within the territory of the Russian Federation and back;

- $\quad$ in case of retirement, lump-sum benefits are paid: for work experience of up to 10 years - twice the size of the allowance, calculated from the average monthly income, from 10 to 15 years - three times, from 15 to 20 
years - four times, over 20 years - five times;

- $\quad$ parents with children under 17 years old are given New Year gifts.

For the purpose of additional motivation, an honour board has been posted on the company's website, and additional medical insurance is provided. One of the important indicators of the integrity and stability of an organisation is staff turnover. A low staff turnover rate indicates a high level of social security of employees and an effective approach to personnel management. We shall consider the dynamics of staff turnover in JSC "UTECKoda" in Figure 1.

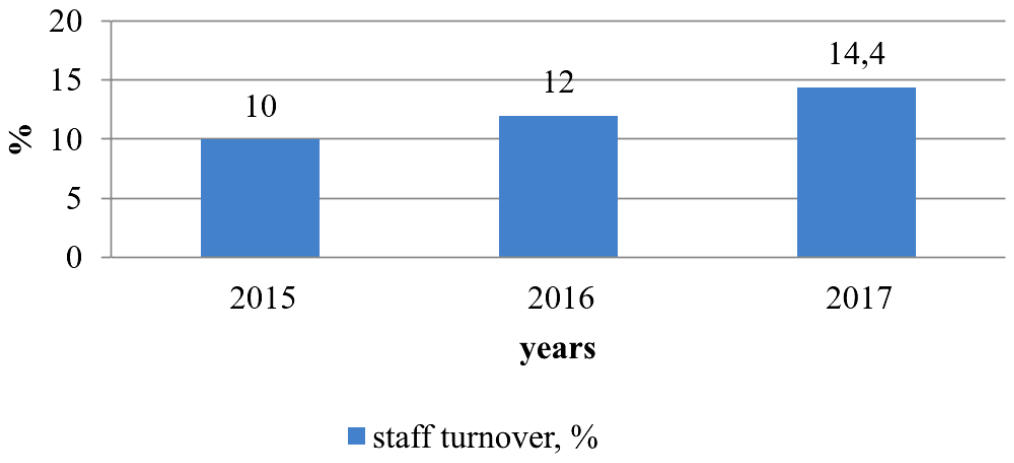

Fig. 1. The dynamics of staff turnover in UTEC-Koda JSC in 2015-2017, \%

Source: compiled by the author based on data from (Media Information, 2020).

According to available data obtained from the annual reports of UTEC-Koda JSC for 2015-2017 we can conclude that the level of turnover in this company is high and increased annually in the analysed period. That is, the measures taken regarding human resources management in this company are not enough to retain employees. We shall compare staff turnover at UTEK-Koda JSC with the same indicator at Rosseti PJSC (Fig. 2).

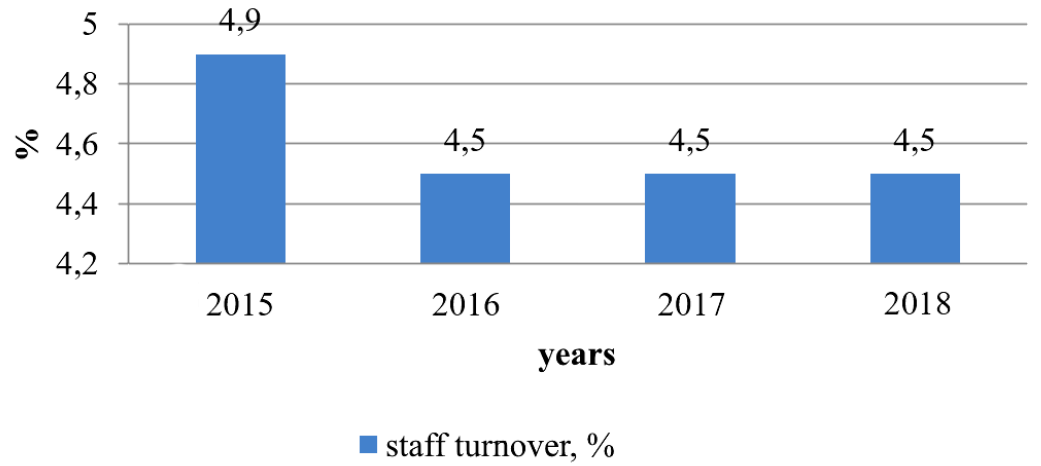

Fig. 2. The dynamics of staff turnover in JSC "Rosseti" in 2015-2018,\%

Source: compiled by the author based on data from (Company's News, 2020).

This company is much larger than UTEC-Koda JSC. The average number of employees of PJSC Rosseti in 2018 amounted to 217 thousand people (including the number of JSC ROSSETI Tyumen over 7 thousand people). The staff turnover in this company in 2015 was $4.9 \%$, and in 2016-2018 was at the level of $4.5 \%$. This level of turnover is in line with the standard and its decrease is a positive fact. The functions of the HR service of PJSC Rosseti include: workforce planning, selection, performance appraisal, salary administration, training, 
development, provisioning, assessment, dismissal. To professionally evaluate the competence and potential of the chief engineers of the subsidiaries and affiliates of PJSC Rosseti, comprehensive assessment activities are regularly carried out with regard to the heads of technical units to the level of electric grid areas (for example, in 2018, over 2 thousand people were evaluated). At all levels of management, a personnel reserve is created. In 2018, the number of updated personnel reserves of subsidiaries and affiliates for senior positions totaled about 15 thousand people. About $70 \%$ of appointments to managerial positions are secured by internal candidates. We shall consider the dynamics of the share of employees with professional education and the level of staffing in 20152017 in JSC "Rosseti Tyumen" in Figure 3.

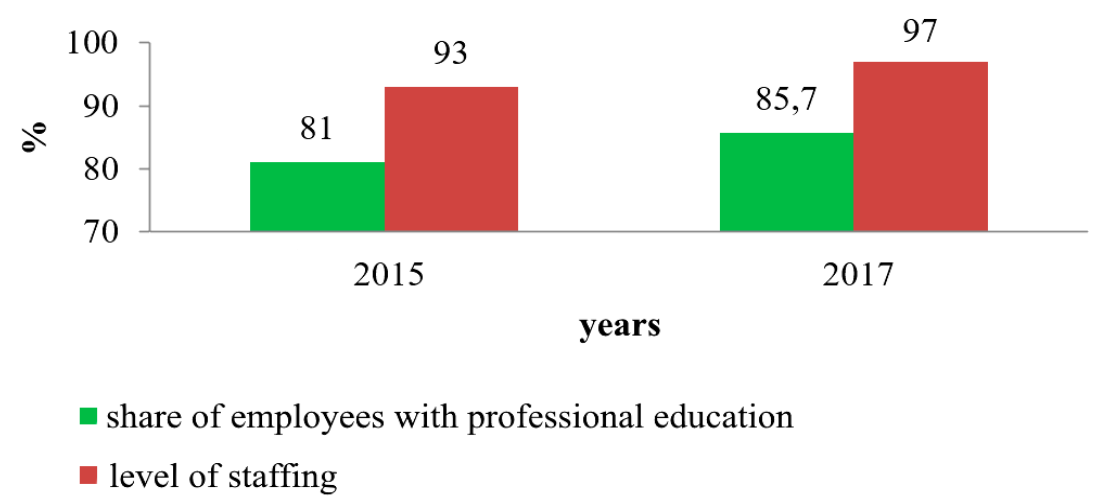

Fig. 3. Dynamics of the share of employees with professional education and staffing levels in 2015-2017, \%

Source: compiled by the author based on data from (Energy News, 2020).

The employees of Rosseti Tyumen JSC noted a high level of staff qualification - in 2017, 85.7\% of employees had professional education. This indicator has increased by 4.7 percentage points since 2015 . The staffing level of JSC Rosseti Tyumen during 2015-2017 was maintained at a fairly high level of not less than 97\%, compared to 2015, the growth was 4 percentage points. The methods of incentives in the company include: establishing a high level of wages, establishing the dependence of wages on the level of productivity and on achieving performance targets, the dependence of wages on the conditions of production activities, promotion of state, industry and corporate awards, assistance in improving housing conditions, additional insurance, organisation of cultural and sports events for employees and their families, etc.

The company has adopted the Digital Transformation 2030 Concept, in accordance with which digital projects have already been implemented in the area of interaction with personnel: conducting evaluation activities with the use of remote testing forms, launching a project to unify and automate HR management business processes aimed at implementing the platform providing a digital format for all personnel processes, which will allow for monitoring and development of the company's work throughout the country. The system of training, retraining, and advanced training is important at all enterprises of the oil and gas industry (Guliyev et al., 2017).

For example, in 2017, employees of UTEK-Koda JSC attended the following advanced training courses: "Civil defence and protection against natural and anthopogenic emergencies", "Labour protection for managers and specialists", "Fire Safety Basics for managers (FSB) and those responsible for fire safety", "Electrical safety", "Electrician for testing and measuring of 4th category". For the following programmes: "Activities in "Preparation and presentation of financial statements of a business entity", "Software Engineer", "Technosphere Security", attended the following seminars: corporate seminar-workshop "On recognition of accounting regulations by federal standards (FSBU). Other relevant changes in the regulatory and legislative framework in 
accounting", "Installation of VLI-0.4 kV, VLZ-6/10 kV with ABC cables. Installation of cable joints 1-35 kV. Innovations in the electric power industry"; workers took part in the electrical engineering forum.

In 2018, Rosseti PJSC received 132 thousand employees or $61 \%$ of the total number of employees trained in 2018, in 2016 this indicator was 50\%, and in $2017-58.7 \%$. That is, there is an annual increase in the number of trained personnel. If we consider the educational activities implemented with the use of training simulators and remote forms of self-training, then the total coverage of employees with training programmes constitutes $100 \%$. We shall analyse the training of personnel at JSC Rosseti Tyumen in 2017-2018 (Table 1).

Table 1. Analysis of personnel training at JSC Rosseti Tyumen in 2017-2018

\begin{tabular}{|c|c|c|c|}
\hline Indicator & 2017 & 2018 & Absolute change \\
\hline Number of employees taking part in training events, people & 3,597 & 3,659 & 62 \\
\hline The total number of staff & 7,418 & 7,375 & -43 \\
\hline The share of employees taking part in training events in the total number of staff, $\%$ & 48.5 & 49.6 & 1.1 \\
\hline
\end{tabular}

Source: compiled by the author based on data from (Energy News, 2020).

The number of employees taking part in training events at JSC Rosseti Tyumen in 2017-2018 increased by 62 people, the share of employees taking part in training events in the total number of personnel increased by 1.1 percentage points, although in comparison with PJSC ROSSETI it is much lower. Next, we shall analyse the training of personnel at Surgutneftegaz PJSC in 2017-2018 (Table 2).

Table 2. Analysis of staff training at Surgutneftegaz PJSC in 2017-2018

\begin{tabular}{|c|c|c|c|}
\hline Indicator & 2017 & 2018 & Absolute change \\
\hline Number of employees taking part in training events, people & 31 & 33.3 & 2.3 \\
\hline The total number of staff & 113.6 & 112.8 & -0.8 \\
\hline The share of employees taking part in training events in the total number of staff, $\%$ & 27.3 & 29.5 & 2.2 \\
\hline
\end{tabular}

Source: compiled by the author based on data from (PJSC "Surgutneftegas", 2020).

The number of employees taking part in training events at Surgutneftegaz PJSC in 2017-2018 increased by 2.3 thousand people, the share of employees taking part in training events in the total number of personnel increased by 2.2 percentage points, although in comparison with PJSC Rosseti and JSC Rosseti Tyumen it is much lower only a third of employees annually improve their level of professional knowledge (Kerimov et al., 2019).

As for the personnel policy in Surgutneftegaz PJSC, the company has a comprehensive system of employee motivation, developed with consideration of strategic objectives of the Company. Motivation tools here include: annual indexation of wages, encouragement (once a year and once a quarter) for the performance of production and technical and economic indicators, bonuses for the performance of especially important tasks, rationalisation work, import substitution, and development of new technologies. Surgutneftegaz PJSC organises "Best in Profession" professional contests and drill crew competitions. This contributes to an increase in the efficiency of employees, helps to creatively address current production matters.

\section{Discussion}

Having analysed the management of human resources at the enterprises of the Tyumen region, we can draw certain conclusions: 


\section{ENTREPRENEURSHIP AND SUSTAINABILITY ISSUES}

ISSN 2345-0282 (online) http://jssidoi.org/jesi/

2020 Volume 8 Number 2 (December)

http://doi.org/10.9770/jesi.2020.8.2(22)

1. In UTEC-Koda JSC, personnel work includes the processes of selection, fitting, hiring, placement, motivation, and staff training. The company has developed a considerable number of ways of motivation: staff at the enterprise are motivated by provision of financial aid in difficult life situations, allocation of rewards on individual holidays, parents are compensated for the costs of preschool education and New Year gifts are presented, corporate trips, leisure trips are organised, photos of advanced workers are placed on the board of honour, the possibility of additional medical insurance is in place. The company has developed a continuing education program. However, despite the measures taken in relation to human resource management, for 20152017, the turnover rate in this company was high and increased annually during the analysed period.

2. The functions of the HR service of PJSC Rosseti include: workforce planning, selection, performance appraisal, salary administration, training, development, provisioning, evaluation, dismissal. The company has adopted the Concept "Digital Transformation 2030", in accordance with which digital projects have already been implemented in interaction with personnel. In this company, low staff turnover is noted over several years, which proves the effectiveness of the ongoing personnel policy.

3. Rosseti Tyumen JSC is part of Rosseti PJSC. The employees of this company have a high level of qualification and a high level of staffing. The company established high salaries, which depend on the level of productivity, on the achievement of performance targets, on conditions of production; employees are encouraged by state, industry, and corporate awards.

4. PJSC Surgutneftegaz has a comprehensive employee motivation system developed with consideration of strategic objectives of the company. Motivation tools here include: annual indexation of wages, bonuses for performing production and technical and economic indicators, bonuses for performing especially important tasks, work on improvement by modification, import substitution, mastering of new technologies, professional skills contests are held. A third of employees annually increase their level of professional knowledge.

The analysis results suggest that in individual companies, mainly in larger ones, the level of staff turnover is lower, which can be explained by a more thought-out policy regarding personnel. In those companies where most of the staff is covered by training programs and digital projects are used in personnel policy, the staff works more stably, contributing to the development of the company. As for the development of improving human resource management, various authors express different opinions. According to N.P. Romanova (2019), it is necessary to study systematically the claims of employees with a view to the rational use of human potential, as there is a correlation between job satisfaction and labour productivity. E. Zavyalova et al. (2017) believe that it is necessary to involve personnel in strategic goal-setting and corporate decision-making, to develop channels of internal and external communication, to provide regular feedback on the performance of employees of all levels, to apply modern methods of personnel assessment, to stimulate various forms of long-term employment (for example, guarantees of a share of profit from the activity of an enterprise).

The authors think that in order to improve the management of human resources at enterprises, the following is necessary: to use digital technologies at all stages of working with personnel, which will improve the efficiency of personnel processes (automate personnel selection, training, assessment, analysis of the reasons for dismissal); it is necessary to study the information on the potential of employees in full detail and use it to achieve the goals of the enterprise; to form a personnel reserve for all employees, and not just for managers; widely introduce intangible instruments of motivation (awards, acknowledgements, flexible work schedule, etc.), accept students for internships, hold open days to form a positive image of the enterprise. Thus, enterprises have the resources and opportunities to improve human resource management. This requires the use of modern tools in the personnel field. Currently, part of the enterprises more successfully manages personnel, another part - less so. Basically, the larger the enterprise, the better its HR management is developed - more motivation tools are applied, the majority 


\section{ENTREPRENEURSHIP AND SUSTAINABILITY ISSUES}

ISSN 2345-0282 (online) http://jssidoi.org/jesi/

2020 Volume 8 Number 2 (December)

http://doi.org/10.9770/jesi.2020.8.2(22)

of personnel processes are computerised - as a result, personnel at such enterprises are more stable (low staff turnover).

\section{Conclusions}

Summarising the results, we can draw certain conclusions. The organisation's human resources constitute one of its largest investments. Human resources constitute the totality of all components (skills, creative abilities) that employees of an enterprise possess. It is the personnel who are responsible for the growth and prosperity of the enterprise, therefore, they need to be treated with attention to maximise their potential in the interests of the enterprise. The efficient use of human resources in an organisation depends on the effective management of human resources. The main responsibilities related to human resource management include: analysis of work and staffing, organisation and use of the workforce, measuring and evaluating the effectiveness of the workforce, introducing employee remuneration systems, professional development of employees, and maintaining the workforce.

The main issues identified in the course of the analysis of indicators describing human resource management at individual enterprises of the Tyumen region (in the Khanty-Mansi Autonomous Okrug and the Yamalo-Nenets Autonomous Okrug) are as follows: high turnover of staff and its growth were noted at UTEC-Koda JSC; at Surgutneftegaz PJSC, only the third part of the employees annually increase their level of professional knowledge (in PJSC Rosseti - 61\%, in JSC Rosseti Tyumen - 49.6\%); not all enterprises link HR policies with the Strategy of the enterprise, not all use digital technologies in HR work. Considering the identified issues, recommendations were developed to improve the situation in personnel management. The author's position on improving human resource management is as follows. It is necessary to use digital technologies to a greater extent in personnel work; maximise the study of information on the potential of employees; form a personnel reserve for all employees; widely introduce intangible motivation tools, work with students and schoolchildren (open days, internships).

Adding together all of the above, it should be noted that further studies are required to improve the efficiency of human resource management in enterprises. Currently, individual scientists are studying the nature and features of human resource management, however, the specifics of personnel management and its potential at particular Russian enterprises remain understudied. The most promising direction for further research on the subject matter is to study the experience of leading companies in developed countries, which will help to decide what mechanisms should be applied at Russian enterprises to improve human resource management.

\section{References}

Akizhanova, D.M.; Satenova, S.K.; Seitova, S.B.; Tulegenova, A.M.; Kaliyeva, S.E. 2018. Universal and culture-specific keywords in business discourse, Papers on Language and Literature, 54(1): 57-64.

Angrave, D.; Kirkpatrick, I. 2016. HR and analytics: Why HR is set to fail the big data challenge, Human Resource Management Journal, 26: $1-11$.

Bamber, G.J.; Bartram, T.; Stanton, P. 2017. HRM and workplace innovations: Formulating research questions, Personnel Review, 46(7): 1216-1227.

Bashynska, I.O. 2015. Using the method of expert evaluation in economic calculations, Actual Problems of Economics, 7(169): 408-412.

Ben-Gal, H.C. 2019. An ROI-based review of HR analytics: Practical implementation tools, Personnel Review, 48(6): $1429-1448$.

Company's News. 2020. https://www.rosseti.ru

Dudin, M.N.; Lyasnikov, N.V.; Senin, A.S.; Sepiashvili, E.N.; Sidorenko, V.N.; Tolmachev, O.M. 2016. Human resource management. 


\section{ENTREPRENEURSHIP AND SUSTAINABILITY ISSUES}

ISSN 2345-0282 (online) http://jssidoi.org/jesi/

2020 Volume 8 Number 2 (December)

http://doi.org/10.9770/jesi.2020.8.2(22)

Moscow: Elit.

Energy News. 2020. https://www.te.ru

Fedotov, A.M.; Murzakhmetov, A.N.; Dyusembaev, A.E. 2018. Expansion of ideas and processes in social and biological communities, Eurasian Journal of Mathematical and Computer Applications, 6(4): 17-28.

Frolova, Y.; Sakulyeva, T.; Hammam, K. 2020. The relationship between corporate responsibility and the performance of the company, Opcion, 36(Special Edition 27): 1134-1150.

Goodall, O. 2019. Staff motivation: Techniques, examples and quotes from SMEs. https://realbusiness.co.uk/staff-motivation-techniquesexamples-quotes/

Gorelov, N.A.; Kruglov, D.V.; Melnikov, O.N. 2016. Human resource management: A modern approach. Moscow: Yurait.

Guliyev, I.S.; Kerimov, V.Yu.; Osipov, A.V.; Mustaev, R.N. 2017. Generation and accumulation of hydrocarbons at great depths under the earth's crust, Socar Proceedings, 1: 4-16.

Kerimov V.Y.; Leonov M.G.; Osipov A.V.; Mustaev R.N.; Khai V. 2019. Hydrocarbons in the basement of the South China Sea (Vietnam) shelf and structural-tectonic model of their formation, Geotektonika, 53(1): 42-59.

Kerimov, V.; Rachinsky, M.; Mustaev, R.; Serikova, U. 2018a. Geothermal conditions of hydrocarbon formation in the South Caspian basin, Iranian Journal of Earth Sciences, 10(1), 78-89.

Kerimov, V.Yu.; Mustaev, R.N.; Osipov, A.V. 2018b. Peculiarities of hydrocarbon generation at great depths in the crust, Doklady Earth Sciences, 483(1): 1413-1417.

Konyavsky, V.; Ross, G. 2020. New method for digital economy user's protection, Lecture Notes in Networks and Systems, 78: 221-230.

Lapidus, A.L.; Kerimov, V.Yu.; Mustaev, R.N.; Movsumzade, E.M.; Salikhova, I.M.; Zhagfarov, F.G. 2018a. Natural bitumens: physicochemical properties and production technologies, Solid Fuel Chemistry, 52(6): 344-355.

Lapidus, A.L.; Kerimov, V.Yu.; Tret'yakov, V.F.; Talyshinskii, R.M.; Ilolov, A.M.; Movsumzade, E.M. 2018b. Extraction of Asphaltite with toluene, Solid Fuel Chemistry, 52(4): 256-259.

Lapshova, O.A. 2020. Human resource management. Moscow: Yurait.

Luenendonk, M. 2014. The Google way of motivating employees. https://www.cleverism.com/google-way-motivating-employees/

Media Information. 2020. https://www.yutek-koda.ru

Meena, R.; Parimalarani, G. 2019. Human capital analytics: A game changer for HR professionals, International Journal of Recent Technology and Engineering, 8: 3963-3965.

Melnyk, N.; Bidyuk, N.; Kalenskyi, A.; Maksymchuk, B.; Bakhmat, N.; Matviienko, O.; Matviichuk, T.; Solovyov, V.; Golub, N.; Maksymchuk, I. 2019. Models and organisational characteristics of preschool teachers' professional training in some EU countries and Ukraine, Zbornik Instituta za Pedagoska Istrazivanja, 51(1): 46-93.

Miethlich, B.; Oldenburg, A.G. 2019. Social inclusion drives business sales: A literature review on the case of the employment of persons with disabilities. Proceedings of the 33rd International Business Information Management Association Conference, IBIMA 2019: Education Excellence and Innovation Management through Vision 2020. April 10-11, Granada, Spain, 6253-6267.

Miethlich, B.; Šlahor, L. 2018. Creating shared value through implementing vocational rehabilitation in the corporate social responsibility strategy: A literature review. Proceedings of the 32nd International Business Information Management Association Conference, IBIMA 2018 - Vision 2020: Sustainable Economic Development and Application of Innovation Management from Regional expansion to Global Growth. November 15-16, Seville, Spain, 1444-1460.

Mukhamadiyeva, G.N.; Kalkayeva, N.; Bopabaev, E.C.; Sailibayeva, Z.Y.; Khamzina, Z.A.; Buribayev, Y.A. 2018. Evolution of labor law in Kazakhstan: Overview and commentary on regulatory objectives and development, Journal of Advanced Research in Law and Economics, 9(8): 2664-2674. 


\section{ENTREPRENEURSHIP AND SUSTAINABILITY ISSUES}

ISSN 2345-0282 (online) http://jssidoi.org/jesi/

2020 Volume 8 Number 2 (December)

http://doi.org/10.9770/jesi.2020.8.2(22)

PJSC “Surgutneftegas”. 2020. https://www.surgutneftegas.ru

Pronina, Z.Yu. 2018. Economics of knowledge: From human resource management to human capital management, Eurasian Scientific Association, 4: 109-111.

Reddy, P.R.; Lakshmikeerthi, P. 2017. HR analytics - An effective evidence based HRM tool, International Journal of Business and Management Invention, 6(7): 23-34.

Romanova, N.P. 2019. Human resource management as a form of using human potential, Bulletin of Transbaikal State University, 2: 8895.

Silagadze, A.; Atanelishvili, T.; Silagadze, N. 2019. Economic doctrines: the origins. Hauppauge: Nova Science Pub Inc.

Stewart, G.L.; Brown, K.G. 2019. Human resource management. New York: Wiley.

Tretyakova, N.V.; Lyzhin, A.I.; Chubarkova, E.V.; Lukiyanova, M.N. 2020. Focus on practical disciplines as a method of developing entrepreneurial mindset, Journal of Entrepreneurship Education, 23(1): 1-9.

Ulrich, D. 2016. HR at a crossroads, Asia Pacific Journal of Human Resources, 54(2): 148-164.

Yessilov, A. 2015. Social work with immigrants in Kazakhstan as means of prevention of the social conflicts in society, Mediterranean Journal of Social Sciences, 6(5): 259-264.

Yessilov, A.B.; Kalashnikova, N.P. 2015. Technology of social work with elderly migrants: International experience and Kazakhstan practice, Advances in Gerontology, 5: 322-326.

Zatsepin, A.M.; Zatsepin, M.N.; Filippova, O.V.; Allalyev, R.M.; Fatkullina, A.A. 2018. The influence of addiction to gambling on the civil capacity of citizens, European Research Studies Journal, 21(4): 588-599.

Zavyalova, E.; Kucherov, D.; Tsybova, V. 2017. Human resources management in Russian companies - leaders of the global economy. Foresight, 11(4): 52-61.

Zeidan, S.; Itani, N. 2020. HR analytics and organizational effectiveness. International Journal on Emerging Technologies, 11(2): 683-688.

Olga V. TOLSTYAKOVA

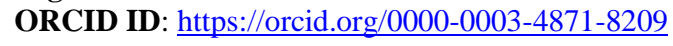

Nazygul T. BATYROVA

ORCID ID: https://orcid.org/0000-0002-6964-6200

Make your research more visible, join the Twitter account of ENTREPRENEURSHIP AND SUSTAINABILITY ISSUES: @Entrepr69728810

Copyright (C) 2020 by author(s) and VsI Entrepreneurship and Sustainability Center

This work is licensed under the Creative Commons Attribution International License (CC BY).

http://creativecommons.org/licenses/by/4.0/

(c) (i) Open Access 